\title{
A systematic review of HIV interventions for black men who have sex with men (MSM)
}

\author{
Cathy Maulsby ${ }^{1 *}$, Greg Millett ${ }^{2}$, Kali Lindsey ${ }^{3}$, Robin Kelley ${ }^{3}$, Kim Johnson $^{3}$, Daniel Montoya ${ }^{3}$ and David Holtgrave ${ }^{1}$
}

\begin{abstract}
Background: Black men who have sex with men (MSM) are disproportionately burdened by HIV/AIDS. Despite this burden there has been a shortage of research on HIV interventions for black MSM. This article provides a comprehensive review of the literature on interventions for black MSM to identify effective HIV prevention intervention strategies for black MSM.

Methods: We searched 3 databases: Pubmed, Scopus, and Google Scholar to identify peer-reviewed articles and used the following search terms: African American or black; MSM or men who have sex with men and women (MSMW); HIV; program or intervention; and evaluation or intervention science or implementation research. We included research articles that assessed interventions for black men who have sex with men. We included studies that used an experimental, quasi-experimental, or pre-post test design as well as formative research studies. We also searched the CDC and NIH websites to identify planned and on-going intervention studies. We identified a total of 23 studies to include in the review.

Results: We identified 12 completed studies of interventions for black MSM. Eight of these 12 interventions aimed to reduce HIV risk behaviors and 5 found a significant reduction in HIV risk behavior over time. We identified 4 health service intervention studies for young black MSM.

Conclusions: Behavior change interventions are effective at reducing HIV risk behaviors among black MSM. However, relying only on behavioral interventions that aim to reduce HIV risk behavior will most likely not have a population-level effect on HIV infection among black MSM. There is a compelling and urgent need to develop and test comprehensive HIV testing, linkage to care, retention in care and adherence interventions for black MSM.
\end{abstract}

Keywords: Black men who have sex with men, HIV, Implementation research, Implementation science, Evaluation

\section{Background}

Men who have sex with men (MSM) are the group most affected by HIV in the United States and, among MSM, black men are disproportionately burdened. In 2010, black men accounted for $36 \%$ of new HIV infections among MSM. The number of new infections among young MSM aged 13-24 increased 22\% from 2008 to 2010, with young black MSM accounting for more than half (55\%) of new HIV infections among young MSM [1]. Disparities in HIV infection by race among MSM can most likely be explained by a range of complex and interconnected factors including: a greater prevalence of sexually transmitted diseases and unrecognized HIV

\footnotetext{
* Correspondence: cmaulsby@jhsph.edu

${ }^{1}$ Department of Health, Behavior and Society, Johns Hopkins Bloomberg

School of Public Health, 624 N. Broadway, Baltimore, MD 21205, USA

Full list of author information is available at the end of the article
}

infection among black MSM; disparities in HIV testing, care and treatment access and use; and social/structural barriers such as income, joblessness, incarceration and discrimination [2-4]. Given the large burden of disease among black MSM, historically there has been a dearth of research on HIV interventions for black MSM [5]. In order to highlight gaps in intervention development and identify effective HIV prevention intervention strategies, this article will provide a comprehensive review of the literature of interventions designed for black MSM. By answering the question "What is the status of HIV prevention intervention research for black MSM", we aim to inform future research and the development of evidence-based programs.

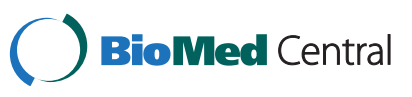




\section{Methods}

We searched 3 databases: Pubmed, Scopus, and Google Scholar to identify peer-reviewed articles. We conducted this electronic database search on May 16, 2012 using the following search terms: African American or black; MSM or men who have sex with men and women (MSMW); HIV; program or intervention; and evaluation or intervention science or implementation research. We included research articles published in the peer review literature and excluded dissertations, editorials, letters and commentaries. We included HIV interventions that were designed for black or African American MSM. Because of the limited research on this topic, we included studies that used an experimental, quasi-experimental, or pre/post test design, as well as formative research that focused on intervention development. We excluded studies that were not conducted in the United States. Data from each study were extracted, organized into summary tables, and discussed by a team of two reviewers. Disagreements were resolved by discussion and consensus. Summary tables highlighted sample population, sample N, primary outcome, study design, key findings and biases. In addition, to give an accurate description of planned and on-going intervention research for black MSM, we searched the National Institute of Health's (NIH) RePORTER and clinical trials database as well as the Center for Disease Control's (CDC) website to identify interventions that met our criteria that were being tested at the time this manuscript was written.

\section{Results}

Our search yielded 127 records. Of these, 96 were excluded based on their title and abstract because they were clearly not relevant to our review. A total of 31 studies were found to be potentially relevant and the full text of these articles or records was retrieved. Of these, 8 were excluded. Three peer articles were excluded because they did not include an analysis of an intervention and 5 peer articles were excluded because the interventions assessed were for MSM regardless of race. A total of 23 studies were included in this review. Sixteen of these studies had findings published in the peer literature and seven were on-going active studies at the time this review was written (Figure 1).

\section{Interventions for black MSM}

Our literature review identified 12 efficacy studies of interventions for black MSM from the peer-reviewed literature. Eight of these aimed to reduce HIV sexual risk behaviors and 4 focused on use of HIV related medical services. Table 1 provides a brief description of these interventions, including the sample, the location for the study, the intervention name, the theory used to guide the intervention, a description of intervention activities,

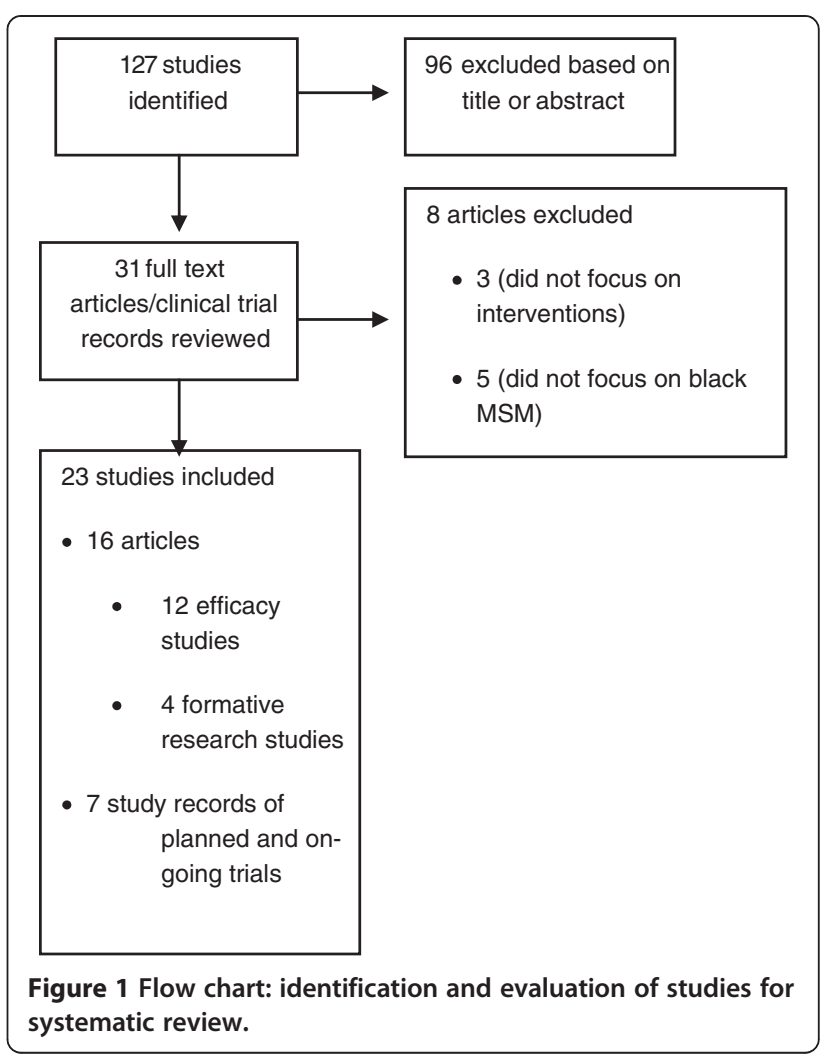

the study design used, the key outcome measured, key findings, and study limitations.

\section{Behavioral risk reduction interventions}

Of the 8 interventions that aimed to reduce HIV sexual risk, 5 used randomized comparison group design [6-10], 2 used a pre-post test design [11,12] and one used a repeated cross-sectional design [13]. Seven of the 8 behavioral risk reduction interventions identified in our review provided a series of health education and skills-building sessions. Five of these interventions were in a group setting [6-10], while the BRUTHAS project was comprised of a series of one-to-one counseling sessions [11] and Connect with Pride was couples based [12]. These multisession interventions addressed topic areas such as condom use, relationship dynamics, skills building around communication and risk reduction. The duration of these interventions varied. For example, Brother to Brother was a three hour intervention while both S-HIM and Many Men, Many Voices included six two-hour sessions.

The one intervention that was not session-based was dup: Defend Yourself! D-up is a DEBI (Diffusion of Effective Behavioral Interventions) that is based on the popular opinion leader model. This model aims to increase safer sex norms by training popular opinion leaders to have risk-reduction conversations with their friends [13].

All of the behavioral risk reduction interventions targeted black MSM, addressed the social context of 
Table 1 HIV Interventions for black MSM

\begin{tabular}{|c|c|c|c|c|c|c|c|c|c|}
\hline $\begin{array}{l}\text { First } \\
\text { author, year }\end{array}$ & $\begin{array}{l}\mathrm{N} \text { total } \\
\text { sample }\end{array}$ & Location & $\begin{array}{l}\text { Intervention } \\
\text { name }\end{array}$ & Theory & $\begin{array}{l}\text { Intervention } \\
\text { description }\end{array}$ & $\begin{array}{l}\text { Study } \\
\text { design }\end{array}$ & $\begin{array}{l}\text { Primary } \\
\text { outcome }\end{array}$ & Findings & Limitations \\
\hline $\begin{array}{l}\text { Hightow- } \\
\text { Weidman (2011) }\end{array}$ & $\begin{array}{l}81 \text { young } \\
\text { MSM of color }\end{array}$ & $\begin{array}{l}\text { North } \\
\text { Carolina }\end{array}$ & $\begin{array}{l}\text { STYLE (Strength } \\
\text { through Youth } \\
\text { Livn' Empowered) }\end{array}$ & NA & $\begin{array}{l}\text { Linkage-to-care program } \\
\text { that provided: social } \\
\text { marketing campaign, } \\
\text { intensive outreach, and a } \\
\text { network of medical-social } \\
\text { support }\end{array}$ & $\begin{array}{l}\text { Pre- and } \\
\text { post- test } \\
\text { (with a } \\
\text { comparison } \\
\text { group) }\end{array}$ & $\begin{array}{l}\text { Viral suppression, } \\
\text { mean and } \\
\text { median change } \\
\text { in CD4, and retention } \\
\text { in care ( } 1 \text { appointment } \\
\text { over a } 4 \text { month period) }\end{array}$ & $\begin{array}{l}1.76 \% \text { viral } \\
\text { suppression at } 12 \\
\text { months 2. } 101 \text { was } \\
\text { the mean change } \\
\text { in CD4 over the } \\
\text { course of the study } \\
\text { 3. OR for clinic visit } \\
\text { STLYE cohort vs. } \\
\text { pre-STYLE cohort } \\
\text { was 2.58 (95\% } \\
\text { Cl 1.34-4.98) }\end{array}$ & $\begin{array}{l}\text { Comparison group } \\
\text { not randomized, } \\
\text { rather matched on } \\
\text { race and age. } \\
\text { Comparison group } \\
\text { attended clinic prior } \\
\text { to STYLE thus } \\
\text { temporal effect might } \\
\text { be due to differences } \\
\text { between groups. } \\
\text { Limited data available } \\
\text { on comparison group } \\
\text { so could not control } \\
\text { for some variables } \\
\text { that might have been } \\
\text { associated with } \\
\text { retention. Survey was } \\
\text { self-report and } \\
\text { administered face-to } \\
\text {-face which might } \\
\text { have introduced bias. } \\
\text { Convenience sample } \\
\text { used which may limit } \\
\text { generalizability. }\end{array}$ \\
\hline Koblin (2011) & 283 black MSM & $\begin{array}{l}\text { New York } \\
\text { City, NY }\end{array}$ & DiSH & $\begin{array}{l}\text { Social } \\
\text { Cognitive } \\
\text { Theory }\end{array}$ & $\begin{array}{l}\text { Five two-hour group } \\
\text { sessions over two weeks. } \\
\text { Sexual risk reduction } \\
\text { information and } \\
\text { exercises integrated into } \\
\text { cooking classes }\end{array}$ & $\begin{array}{l}\text { Randomized } \\
\text { comparison } \\
\text { group }\end{array}$ & $\begin{array}{l}\text { Unprotected anal and } \\
\text { receptive intercourse }\end{array}$ & $\begin{array}{l}\text { 1. Declines from } \\
\text { baseline to } 3 \text { months } \\
\text { in percentage } \\
\text { reporting UIAI, URAI, } \\
\text { UIAI with Unknown/ } \\
\text { serodiscordant partners } \\
\text { and URAI with } \\
\text { unknown/ } \\
\text { serodiscordant partners } \\
\text { for all participants, No } \\
\text { significant differences } \\
\text { in outcomes by control } \\
\text { arm. }\end{array}$ & $\begin{array}{l}\text { Data were self-report } \\
\text { and could be subject } \\
\text { to social desirability } \\
\text { bias and recall bias. } \\
\text { Sample size was too } \\
\text { small to conduct } \\
\text { subgroup analyses. } \\
\text { Convenience sample } \\
\text { used which may limit } \\
\text { generalizability. }\end{array}$ \\
\hline Wohl (2011) & $\begin{array}{l}61 \text { young } \\
\text { MSM of color }\end{array}$ & Los Angeles & NA & NA & $\begin{array}{l}\text { Youth-focused case } \\
\text { management with } \\
\text { weekly sessions for two } \\
\text { months and monthly } \\
\text { sessions for the following } \\
\text { twenty-two months }\end{array}$ & $\begin{array}{l}\text { Pre- and } \\
\text { post- test }\end{array}$ & $\begin{array}{l}\text { Retention in care ( } 2 \text { or } \\
\text { more HIV care } \\
\text { appointments in the } \\
\text { past } 6 \text { months) }\end{array}$ & $\begin{array}{l}\text { 1. } 90 \% \text { participants } \\
\text { retained in care at } 3 \\
\text { months and } 70 \% \text { at } 6 \\
\text { months } 2 \text {. Among } 33 \\
\text { participants with } \\
\text { previous intermittent } \\
\text { care, percentage } \\
\text { attending clinic visits } \\
\text { rose from } 7 \% \text { to } 73 \% \\
\text { over } 6 \text { months } \\
(p<0.0001) .3 \text {. Retention }\end{array}$ & $\begin{array}{l}\text { No control group for } \\
\text { this study, rather } \\
\text { participants acted as } \\
\text { their own controls for } \\
\text { pre and post analyses. } \\
\text { Pre/post designs } \\
\text { suffer from weak } \\
\text { internal validity. Small } \\
\text { sample size limited } \\
\text { ability to calculate OR } \\
\text { estimates. }\end{array}$ \\
\hline
\end{tabular}




$\begin{array}{lll}\text { Wu (2011) } 68 \text { black MSM New York } \begin{array}{ll}\text { Connect with } \\ \text { Pride }\end{array} & \begin{array}{l}\text { Social } \\ \text { Cognitive } \\ \text { Theory }\end{array} & \begin{array}{l}\text { Ninety minute } \\ \text { intervention sessions } \\ \text { delivered to a couple } \\ \text { that focused on HIV } \\ \text { transmission and risk, }\end{array} \\ & \begin{array}{l}\text { social and regulatory } \\ \text { skills building, condom } \\ \text { use and harm reduction. }\end{array}\end{array}$

Mangus (2010) 224 young National Special Projects NA MSM of color of National Significance (SPNS) in HIV care at 6

Convenience sample used which may limit months associated generalizability.

of intervention visits

(UOR $10.5(95 \%$ Cl 1.196.6, $\mathrm{p}=0.038)$.

1. Baseline to follow-up No control group for participants reported this study, rather significantly fewer participants acted as sexual partners (mean their own controls for 4.5 vs 1.6), episodes of pre and post analyses. UAI (mean 13.3 vs 2.2), Pre/post designs and greater condom suffer from weak use with main partners internal validity. Small (mean proportion 18\% sample size limited vs $72 \%$ ) $\quad$ ability to calculate $O R$ estimates. Data were self-report and could be subject to social desirability bias and recall bias. However, data were collected using ACASI which should reduce social desirability bias.

Convenience sample used which may limit generalizability.

1. Receipt of any

program services was negatively associated

No control group for this study, rather participants acted as projects across eight post-test project sites. their own controls for

pre and post analyses. Pre/post designs suffer from weak internal validity. Data were self-report and could be subject to social desirability bias and recall bias. Convenience sample used which may limit generalizability 
Table 1 HIV Interventions for black MSM (Continued)

\begin{tabular}{|c|c|c|c|c|c|c|c|c|c|}
\hline Operario (2010) & $\begin{array}{l}36 \text { young } \\
\text { black MSM }\end{array}$ & Oakland, CA & $\begin{array}{l}\text { The Bruthas } \\
\text { Project }\end{array}$ & $\begin{array}{l}\text { Information- } \\
\text { motivation- } \\
\text { behavioral } \\
\text { skills model, } \\
\text { AIDS Risk } \\
\text { Reduction } \\
\text { Model }\end{array}$ & $\begin{array}{l}\text { Four one-hour one-on-one } \\
\text { HIV counseling sessions. } \\
\text { Topics included: general } \\
\text { HIV risk reduction } \\
\text { counseling, partner } \\
\text { dynamics with women, } \\
\text { partner dynamics with } \\
\text { men, triggers for unsafe } \\
\text { sex, and risk reduction goal } \\
\text { setting }\end{array}$ & $\begin{array}{l}\text { Pre- and } \\
\text { post-test }\end{array}$ & $\begin{array}{l}\text { Unprotected anal } \\
\text { intercourse }\end{array}$ & $\begin{array}{l}\text { 1. Significant reduction } \\
\text { in UIAI ( } 58.3 \% \text { vs. } \\
33.3 \%, p=0.02) \text {, URAI } \\
\text { ( } 44.4 \% \text { vs. } 22.2 \% \\
\text { ( } p=0.04 \text { ), mean number } \\
\text { female partners } \\
\text { unprotected sex ( } 3.5 \text { vs. } \\
\text { 1.7, } p=0.01 \text { ), mean } \\
\text { number male partners } \\
\text { unprotected sex ( } 1.8 \text { vs. } \\
0.9, p=0.02 \text { ), sex under } \\
\text { influence drugs ( } 86.1 \% \\
\text { vs. } 52.8 \%, p=0.00) 2 . \\
\text { Increase in mean social } \\
\text { support }(2.9 \text { vs. } 3.4, \\
p=0.02), \text { mean self- } \\
\text { esteem ( } 3.7 \text { vs. } 4.1, \\
p=0.00) \text {, loneliness ( } 2.2 \\
\text { vs. } 1.0, p=0.02 \text { ) }\end{array}$ & $\begin{array}{l}\text { No control group for } \\
\text { this study, rather } \\
\text { participants acted as } \\
\text { their own controls for } \\
\text { pre and post analyses. } \\
\text { Pre/post designs } \\
\text { suffer from weak } \\
\text { internal validity. Data } \\
\text { were self-report and } \\
\text { could be subject to } \\
\text { social desirability bias } \\
\text { and recall bias. } \\
\text { However, data were } \\
\text { collected using ACASI } \\
\text { which should reduce } \\
\text { social desirability bias. } \\
\text { Convenience sample } \\
\text { used which may limit } \\
\text { generalizability. High } \\
\text { rates of attrition. }\end{array}$ \\
\hline Outlaw (2010) & 96 black MSM & $\begin{array}{l}\text { Detroit, } \\
\text { Michigan }\end{array}$ & NA & $\begin{array}{l}\text { Self- } \\
\text { Perception } \\
\text { Theory, } \\
\text { Decision } \\
\text { Balance } \\
\text { Theory, } \\
\text { Trans- } \\
\text { theoretical } \\
\text { Model }\end{array}$ & $\begin{array}{l}\text { Thirty minute field } \\
\text { outreach session with } \\
\text { peers using motivational } \\
\text { interviewing }\end{array}$ & $\begin{array}{l}\text { Randomized } \\
\text { comparison } \\
\text { group }\end{array}$ & $\begin{array}{l}\text { HIV counseling and } \\
\text { testing \& returning for } \\
\text { test results }\end{array}$ & $\begin{array}{l}\text { 1. Intervention group } \\
\text { more likely to receive } \\
\text { HIV counseling and } \\
\text { testing ( } 49 \% \text { vs. } 20 \% \text {, } \\
p=0.000) \\
\text { 2. Intervention group } \\
\text { more likely to return } \\
\text { for their test results } \\
(98 \% \text { vs. } 72 \%, p=0.001)\end{array}$ & $\begin{array}{l}\text { Convenience sample } \\
\text { used which may limit } \\
\text { generalizability. Peer } \\
\text { outreach workers } \\
\text { were not blinded to } \\
\text { treatment condition } \\
\text { which could bias } \\
\text { results; however this } \\
\text { was minimized by the } \\
\text { use of objective } \\
\text { outcome measures. }\end{array}$ \\
\hline Coleman (2009) & $\begin{array}{l}82 \text { African } \\
\text { American MSM } \\
50+\text { HIV+ }\end{array}$ & Pennsylvania & NA & $\begin{array}{l}\text { Social } \\
\text { Cognitive } \\
\text { Theory, } \\
\text { Theory of } \\
\text { Reasoned } \\
\text { Action, and } \\
\text { Theory of } \\
\text { Planned } \\
\text { Behavior }\end{array}$ & $\begin{array}{l}\text { Four two-hour sessions. } \\
\text { Topics included: stigma, } \\
\text { alienation, co-morbidities } \\
\text { associated with aging } \\
\text { and HIV, and condom } \\
\text { negotiation. }\end{array}$ & $\begin{array}{l}\text { Randomized } \\
\text { comparison } \\
\text { group }\end{array}$ & $\begin{array}{l}\text { Consistent condom } \\
\text { use }\end{array}$ & $\begin{array}{l}\text { 1. Risk reduction group } \\
\text { OR } 2.04 \text { ( } 95 \% \text { Cl: } 0.48- \\
8.77, \mathrm{p}=0.336) \text { times as } \\
\text { likely report consistent } \\
\text { condom use in the } \\
\text { past } 3 \text { months. } \\
\text { 2. Among men who } \\
\text { did not report } \\
\text { consistent condom use } \\
\text { at baseline, risk } \\
\text { reduction group OR }\end{array}$ & $\begin{array}{l}\text { Convenience sample } \\
\text { used which may limit } \\
\text { generalizability. Data } \\
\text { were self-report and } \\
\text { could be subject to } \\
\text { social desirability bias } \\
\text { and recall bias. } \\
\text { Intervention used a } \\
\text { female facilitator } \\
\text { which might have }\end{array}$ \\
\hline
\end{tabular}




\begin{tabular}{|c|c|c|c|c|c|c|c|}
\hline Wilton (2009) & 338 black MSM & $\begin{array}{l}\text { New York } \\
\text { City, NY }\end{array}$ & $\begin{array}{l}\text { Many Men, Many } \\
\text { Voices (3MV) } \\
\text { (DEBI) }\end{array}$ & $\begin{array}{l}\text { Social } \\
\text { Cognitive } \\
\text { Theory, } \\
\text { Behavior } \\
\text { Skills } \\
\text { Acquisition } \\
\text { Model, } \\
\text { Trans- } \\
\text { theoretical } \\
\text { Model, } \\
\text { Decision } \\
\text { Balance } \\
\text { Model }\end{array}$ & $\begin{array}{l}\text { Six two- to three-hour } \\
\text { sessions. Topics included: } \\
\text { racism, homophobia, } \\
\text { sexual relationship } \\
\text { dynamics, risk reduction, } \\
\text { intentions to change, } \\
\text { capacity to change, } \\
\text { partnership selection, } \\
\text { communication, } \\
\text { negotiation, social } \\
\text { support, and problem } \\
\text { solving. }\end{array}$ & $\begin{array}{l}\text { Randomized } \\
\text { comparison } \\
\text { group }\end{array}$ & $\begin{array}{l}\text { Unprotected anal } \\
\text { intercourse }\end{array}$ \\
\hline
\end{tabular}

\begin{tabular}{|c|c|c|c|c|c|c|c|}
\hline Williams (2008) & $\begin{array}{l}137 \text { HIV } \\
\text { positive } \\
\text { African } \\
\text { American and } \\
\text { Latino MSM }\end{array}$ & Los Angeles & $\begin{array}{l}\text { Sexual Health } \\
\text { Intervention for } \\
\text { Men (S-HIM) }\end{array}$ & $\begin{array}{l}\text { Social } \\
\text { Cognitive } \\
\text { Theory }\end{array}$ & $\begin{array}{l}\text { Six two hour session } \\
\text { intervention. Topics } \\
\text { included; gender and } \\
\text { ethnicity, early } \\
\text { socialization around } \\
\text { gender and culture, } \\
\text { stigma, problem solving, } \\
\text { psychological well-being, } \\
\text { recognizing triggers }\end{array}$ & $\begin{array}{l}\text { Randomized } \\
\text { comparison } \\
\text { group }\end{array}$ & $\begin{array}{l}\text { Unprotected anal } \\
\text { intercourse }\end{array}$ \\
\hline Jones (2008) & $\begin{array}{l}\text { Approximately } \\
300 \text { black MSM }\end{array}$ & $\begin{array}{l}\text { Three cities } \\
\text { in North } \\
\text { Carolina }\end{array}$ & $\begin{array}{l}\text { d-up: defend } \\
\text { yourself (DEBI) }\end{array}$ & $\begin{array}{l}\text { Diffusion of } \\
\text { Innovations }\end{array}$ & $\begin{array}{l}\text { Popular opinion leader } \\
\text { model. Opinion leaders } \\
\text { trained during four two- } \\
\text { hour sessions. Topics } \\
\text { included: racism, } \\
\text { homophobia, bisexuality, } \\
\text { employment and } \\
\text { poverty, religion, } \\
\text { condom use } \\
\text { demonstration, and skills } \\
\text { building in risk reduction } \\
\text { communication. }\end{array}$ & $\begin{array}{l}\text { Repeated } \\
\text { cross-section } \\
\text { surveys at } 4 \\
\text { equally } \\
\text { spaced time } \\
\text { points }\end{array}$ & $\begin{array}{l}\text { Unprotected anal } \\
\text { intercourse }\end{array}$ \\
\hline
\end{tabular}

5.18 (95\% Cl: .97-27.78) times more likely to report consistent condom use at 3 months.

1. UAl casual partner (95\% Cl $0.14-0.83))$ and intervention which $0.09-0.65) 3.24 \%$ might bias the study 0.0.65) 3. GEE towards finding months case vs. 6 control: RR UIAI with casual partners $(0.49$ $(95 \%$ Cl 0.28-0.87)) Convenience samp. used which may limit generalizability. Data were self-report and could be subject to social desirability bias and recall bias. However, data were collected using ACASI which should reduce social desirability bias.

1. Sample as a whole reported reductions in sexual risk behaviors and number of sex partners from baseline to post-test, and from 3 to 6 months. 2 .

Decrease in sexual risk behaviors from baseline to post-test only significant for S-

HIM participants

$\begin{array}{ll}\text { 1. Found significant } & \text { No control group for } \\ \text { linear trends in } & \text { this study which may } \\ \text { decreases in UIAI, URAI, } & \text { weaken internal } \\ \text { and UAI with male } & \text { validity. Data were } \\ \text { partners at 4, 8, and 12 } & \text { self-report and could } \\ \text { months 2. At 12 } & \text { be subject to social } \\ \text { months, mean number } & \text { desirability bias and } \\ \text { of URAl partners } & \text { recall bias. However, } \\ \text { decreased by 40.5\%, } & \text { data were collected } \\ \text { mean number of UIAl } & \text { using self- } \\ \text { episodes decreased by } & \text { administered surveys } \\ 53.0 \%, \text { mean number } & \text { on handheld } \\ \text { of URAl decreased by } & \text { computers. } \\ 56.8 \%, \text { percentage } & \text { Convenience sample }\end{array}$

Convenience sample used which may limit generalizability. Data were self-report and could be subject to social desirability bias and recall bias. ncrease social 
Table 1 HIV Interventions for black MSM (Continued)

\begin{tabular}{|c|c|c|c|c|c|c|c|c|c|}
\hline & & & & & & & & $\begin{array}{l}\text { condom use UIAI } \\
\text { increased by } 23.0 \% \\
\text { and percentage } \\
\text { condom use URAI } \\
\text { increased } 30.3 \% \text {. }\end{array}$ & $\begin{array}{l}\text { used which may limit } \\
\text { generalizability. }\end{array}$ \\
\hline Peterson (1996) & $\begin{array}{l}318 \text { African } \\
\text { American gay } \\
\text { and bisexual } \\
\text { men }\end{array}$ & $\begin{array}{l}\text { San } \\
\text { Francisco } \\
\text { Bay Area }\end{array}$ & $\begin{array}{l}\text { Brother to } \\
\text { Brother }\end{array}$ & $\begin{array}{l}\text { Social } \\
\text { Cognitive } \\
\text { Theory and } \\
\text { AIDS Risk } \\
\text { Reduction } \\
\text { Model }\end{array}$ & $\begin{array}{l}\text { Experimental } \\
\text { intervention was either } \\
\text { one three-hour session } \\
\text { or thee three-hour } \\
\text { sessions. Topics included: } \\
\text { racial and sexual identity, } \\
\text { perceptions of HIV risk, } \\
\text { HIV risk education, } \\
\text { assertiveness training, } \\
\text { and behavioral } \\
\text { commitment. }\end{array}$ & $\begin{array}{l}\text { Randomized } \\
\text { comparison } \\
\text { group }\end{array}$ & $\begin{array}{l}\text { Unprotected anal } \\
\text { intercourse }\end{array}$ & $\begin{array}{l}\text { 1. Participants in the } \\
\text { triple session group } \\
\text { reduced UAl from } 46 \% \\
\text { to } 20 \% \text { at } 12 \text { months } \\
\text { and from } 45 \% \text { to } 20 \% \\
\text { at } 18 \text { months } 2 \text {. } \\
\text { Participants in the } \\
\text { single session } \\
\text { intervention reduced } \\
\text { UAl from } 47 \% \text { to } 38 \% \\
\text { at } 12 \text { months and } 50 \% \\
\text { to } 38 \% \text { at } 18 \text { months } 3 \text {. } \\
\text { Participants in the } \\
\text { control group had no } \\
\text { change in UAl at } 12 \\
\text { months (26\% to } 23 \%) \\
\text { and } 18 \text { months (24\% } \\
\text { to } 18 \% \text { ) }\end{array}$ & $\begin{array}{l}\text { Convenience sample } \\
\text { used which may limit } \\
\text { generalizability. Data } \\
\text { were self-report and } \\
\text { could be subject to } \\
\text { social desirability bias } \\
\text { and recall bias. High } \\
\text { rates of attrition } \\
\text { limited ability to } \\
\text { accurately detect } \\
\text { differences between } \\
\text { groups however used } \\
\text { an intent-to-treat } \\
\text { approach. Selection } \\
\text { bias might be present } \\
\text { as there were } \\
\text { differences between } \\
\text { exposure and } \\
\text { comparison group at } \\
\text { baseline. }\end{array}$ \\
\hline
\end{tabular}


HIV risk reduction for black MSM by including discussion in areas such as stigma, racism, masculinity and homophobia, and were grounded in theory. Interventions were tailored for young MSM [13,14], MSM of unknown or negative HIV status [10], older HIV-positive MSM [6], MSM with a history of child abuse [9], men who have sex with men and women [11], and MSM that use methamphetamines [12].

Seven of the behavioral interventions assessed unprotected anal intercourse as their primary outcome of interest [7-13] and one assessed consistent condom use [6]. Of the 8 behavioral interventions identified by this review, 5 were found to reduce HIV sexual risk behavior. The evaluation of d-up! measured unprotected receptive and insertive anal intercourse at 4 months, 8 months, and 12 months. The study found reductions at all time points. At 12 months, the study found $31.8 \%$ reduction in any unprotected anal intercourse as well as a $40.5 \%$ reduction in mean number of unprotected receptive anal sex partners [13]. Peterson found that Brother to Brother participants who engaged in a triple session intervention reduced frequency of unprotected anal intercourse from 45\% (95\% CI $0.33-0.57)$ at baseline to $20 \%(95 \%$ CI $0.12-0.31)$ at 18 months. Participants who engaged in a single-session intervention saw only slight decreases in unprotected sex from baseline to 18 months (50\% (95\% CI 0.37-0.63) to $38 \%$ (95\% CI 0.26-0.51). Among the control group, frequency of risky sex remained constant over time, $24 \%$ (95\% CI 0.14-0.38) at baseline versus $18 \%$ (95\% CI 0.09 0.32 ) at 18 months. These results suggest the superiority of the triple session over the single session in reducing risky sexual behavior [8]. Wilton found that Many Men, Many Voices participants, when compared to controls, had significant reductions in mean number of any unprotected anal intercourse episodes with casual partners $(\mathrm{RR}=0.34 ; 95 \% \mathrm{CI}=0.14-0.83)$ at 6 months and male sex partners $(\mathrm{RR}=0.75 ; 95 \% \mathrm{CI}=0.57-0.98)$ at 3 months [10]. At 3 months, the BRUTHAS project found significant reductions in unprotected receptive (44.4\% versus $22.2 \%$, $p=0.04)$ and insertive anal intercourse $(58.3 \%$ versus $33.3 \%, p=0.02)$, as well as reductions in mean number of female (3.5 versus $1.7, p=0.01$ ) and male ( 1.8 versus 0.9 , $p=0.02)$ unsafe sex partners and sex under the influence of drugs $(86.1 \%$ versus $52.8 \%, p=0.00)$. The BRUTHAS project also found increases in mean social support (2.9 versus $3.4, p=0.02)$ and mean self-esteem (3.7 versus 4.1, $p=0.00)$ and decreases in mean loneliness (2.2 versus 1.9 , $p=0.02$ ) [11]. Connect with Pride found that at 2 months follow-up, study participants reported significantly fewer sexual partners (mean 4.5 versus 1.6) and mean number of episodes of UAI with main partners (13.3 versus 2.2) [12].

Of the 8 behavioral risk reduction interventions included in this review, 3 had inconclusive findings. SHIM found a reduction in sexual risk behavior for the whole sample from baseline to post-test and from 3 to 6 months and no significant main effect of condition on level of sexual behavior. The study also found that there was no main effect of condition on number of sex partners or depression [9].

The evaluation of a HIV risk reduction intervention for older HIV seropositive black men found that MSM who were exposed to the intervention were equally likely to use condoms consistently compared to controls $(\mathrm{OR}=2.04 ; 95 \% \mathrm{CI}=0.48-8.77, p=0.336)$. However, among men who did not report consistent condom use at baseline, exposure to the intervention was marginally associated with an increase in consistent condom use at 3 months (OR 5.18; 95\% CI=0.97-27.78, $p=0.054$ ) [6].

The DiSH study found significant decreases among all participants from baseline to 3 months in unprotected insertive anal intercourse (UIAI), unprotected receptive anal intercourse (URAI), UIAI with unknown or serodiscordant partners, and URAI with unknown or serodiscordant partner $(\mathrm{p}<.0001$ for all). However, the study arm did not differ significantly from the control arm for these outcomes. The study also found declines for all participants from baseline to 3 months in number of male partners and mean number of unprotected anal intercourse partners and increases in condom use. Again, these findings did not differ significantly by study arm [7].

\section{HIV service interventions}

We identified 4 peer review articles on evaluated health service interventions. A study by Outlaw aimed to increase HIV testing among young black MSM. The study found that men exposed to the motivational interviewing condition were more likely to receive HIV counseling and testing $(49.0 \%$ versus $20.0 \%, \mathrm{p}=0.000)$ and that exposed individuals were more likely to return for their test results than men who received standard care $(98.0 \%$ versus $72.0 \%, \mathrm{p}=0.001$ ) [15]. Motivational interviewing is a client-centered goal-oriented communication method to increase motivation and confidence for behavior change [16].

The Health Resources Service Administration (HRSA) HIV/AIDS Bureau's Special Projects of National Significance (SPNS) was a national multi site enhanced linkage-to-care program implemented for young MSM (YMSM) of color. A cross-site evaluation of 224 young MSM of color found that enhanced linkage-to care services reduced the odds of having a missed HIV medical visit $(\mathrm{AOR}=0.16 ; 95 \% \mathrm{CI}=0.03-0.92)$. In addition, the evaluation found that feeling respected at the clinic was associated with retention in care [14]. One of the demonstration sites for SPNS, Los Angeles, conducted an evaluation of their case management intervention. The intervention included weekly case management visits for 
2 months and monthly visits for the subsequent 22 months. The evaluation used a pre/post test design without a comparison group. The evaluation found that among intermittent care participants $(n=33)$, the average number of HIV care visits increased from 0.2 to 5.5 from baseline to 6 months $(p=<0.0001)$ and that $82 \%$ of participants who had been in intermittent care were retained in care at 6 months. (Intermittent care was defined as having less than 2 HIV primary care visits in the past 6 months). The evaluation also found a significant dose-response trend between number of hours in the intervention and retention in HIV care $(p=0.02)$ [17].

STYLE (Strength Through Youth Livin' Empowered) is a SPNS intervention conducted in North Carolina that aimed to diagnose, engage, and retain minority young MSM (YMSM) in HIV primary care services. The intervention included a social marketing campaign, outreach to minority YMSM, and the availability of a medicalsocial support network that included a peer outreach worker, a physician, a case manager, support groups, research staff and local AIDS social service organizations. The intervention used a pre/post test design with a comparison group comprised of clinic participants prior to the start of the STYLE program. The intervention enrolled 81 participants and found that $83 \%$ of participants had at least one medical visit every 4 months (retained in care). The odds ratio for attending a clinic visit was 2.58 for the STYLE cohort compared to the pre-STYLE cohort (95\% CI 1.34-4.98) [18].

\section{Intervention development}

We identified four formative research articles in the peer-reviewed literature that focused on intervention development (Table 2). An article by Hightow-Weidman details the formative process used to develop HEALTHEMPOWERMENT.org, a theory-based online HIV/STI prevention intervention for young black MSM [19]. Formative research was conducted in three phases. Focus groups, semi-structured interviews and an expert panel contributed to the first version of the site. Two rounds of usability testing resulted in additional versions that included new features such as added intervention components, topic areas, and a community networking function. The formative research found that the development of a culturally meaningful and developmentally appropriate interactive HIV/STI website was a highly iterative process [19].

A study by Williams described the formative research and development process that contributed to the creation of MAALES, an intervention for black MSMW. The intervention was informed by 9 focus groups and 20 one-to-one interviews and included pilot intervention testing. MAALES intervention involves 6 sessions covering topics such as meaning ascribed to an African
American male identity, HIV in the African American community, risk assessment, harm reduction, communication skills building, and goal setting. In addition to reducing HIV risk behavior, the intervention was also designed to increase racial and cultural pride. Initial early evaluation activities and case study data from MAALES suggest a high level of participant satisfaction [20].

A paper by $\mathrm{Wu}$ describes the formative research findings that were used to inform the adaptation of an intervention for methamphetamine-involved heterosexual couples, Connect, into an intervention for methamphetamine-involved African American MSM couples. A total of 8 couples participated in 6 focus group discussions. The study developed a relationship-oriented framework for methamphetamineinvolved African American male couples. The couples intervention was then divided into component activities; each component activity was revised to adhere to the framework and reconstructed. The intervention team then planned to pilot test the revised intervention with a small sample of its target audience [21]. The resulting pilot intervention, Connect with Pride, was discussed in the previous section [12].

A recent article by Jaganatha described the training of peer leaders to initiate HIV discussions on social networking sites. The study, called HOPE (Harnessing Online Peer Education), adapted the community popular opinion leader method of using influential members of the community to motivate behavior change for social networking sites. The study targeted Latino and African American MSM. The peer training included 5 broad topic areas: recruitment, HIV knowledge, social context of stigma and cultural barriers to HIV prevention, communication and the creation of effective health communication messages, and ethical considerations of using social media as health prevention tool [22].

\section{Planned and on-going research}

When we conducted on-line searches of the CDC (cdc. gov ) and NIH (projectreporter.nih.gov/reporter.cfm and clinicaltrials.gov) we identified seven additional studies that are in various stages of implementation. The Safer Sex Program for Young African-American Men is a randomized control trial that will test the efficacy of an intervention to reduce STD and HIV acquisition among young black MSM. This clinic-based study aims to be completed in 2016. Connect'n Unite: Couples-Based HIV/STI Prevention for Drug-Involved, Black MSM $(\mathrm{CNU})$ is a randomized clinical control trial to test the efficacy of the Connect with Pride intervention. This study aims to be completed by 2015 . We identified five studies that were actively recruiting at the time this paper was written, three of which focus on MSMW. Project Power is an internet-based intervention for MSMW that includes three two-hour sessions facilitated by health educator on HIV risk reduction. The intervention 
Table 2 Formative research for HIV interventions for black MSM

\begin{tabular}{|c|c|c|c|c|c|c|c|}
\hline $\begin{array}{l}\text { First } \\
\text { author, } \\
\text { year }\end{array}$ & $\begin{array}{l}N \text { total } \\
\text { sample }\end{array}$ & Location & Intervention Name & Theory/Model & Description & $\begin{array}{l}\text { Evaluation } \\
\text { design }\end{array}$ & Findings \\
\hline \multicolumn{8}{|c|}{ Formative Research and Intervention Development } \\
\hline $\begin{array}{l}\text { Jagantha } \\
\text { (2011) }\end{array}$ & NA & California & $\begin{array}{l}\text { Harnessing Online Peer } \\
\text { Education (HOPE) }\end{array}$ & $\begin{array}{l}\text { Community } \\
\text { Population Opinion } \\
\text { Leader Model }\end{array}$ & $\begin{array}{l}\text { Training of peer } \\
\text { leaders in HIV } \\
\text { prevention } \\
\text { education and } \\
\text { behavior change to } \\
\text { interact with } \\
\text { participants on a } \\
\text { Facebook group. }\end{array}$ & $\begin{array}{l}\text { Pre-post } \\
\text { questionnaire, } \\
\text { activity log, } \\
\text { content } \\
\text { analysis of } \\
\text { Facebook } \\
\text { discussion, and } \\
\text { interviews }\end{array}$ & $\begin{array}{l}\text { Evaluation results not } \\
\text { included in article }\end{array}$ \\
\hline $\begin{array}{l}\text { Hightow- } \\
\text { Weidman } \\
\text { (2011) }\end{array}$ & NA & $\begin{array}{l}\text { North } \\
\text { Carolina }\end{array}$ & $\begin{array}{l}\text { HEALTHMPOWERMENT. } \\
\text { ORG }\end{array}$ & $\begin{array}{l}\text { Institute of } \\
\text { Medicine's } \\
\text { Integrated Model of } \\
\text { Behavior Theory }\end{array}$ & $\begin{array}{l}\text { Formative research } \\
\text { for website } \\
\text { development }\end{array}$ & $\begin{array}{l}3 \text { focus groups, } \\
\text { semi-structured } \\
\text { interviews, and } \\
\text { two rounds of } \\
\text { usability } \\
\text { testing }\end{array}$ & $\begin{array}{l}\text { 1. Website development } \\
\text { was an iterative process } \\
\text { 2. Usability testing } \\
\text { suggests that site is high } \\
\text { rates of satisfaction, } \\
\text { content acceptability, } \\
\text { and usability }\end{array}$ \\
\hline Wu (2010) & $\begin{array}{l}8 \text { couples } \\
\text { with at } \\
\text { least one } \\
\text { African } \\
\text { American } \\
\text { partner } \\
\text { per couple }\end{array}$ & $\begin{array}{l}\text { New } \\
\text { York }\end{array}$ & $\begin{array}{l}\text { Pilot version of } \\
\text { Connect with Pride }\end{array}$ & $\begin{array}{l}\text { Theory of Behavior } \\
\text { Change }\end{array}$ & $\begin{array}{l}\text { Formative research } \\
\text { for intervention } \\
\text { adaptation }\end{array}$ & $\begin{array}{l}6 \text { focus group } \\
\text { discussions }\end{array}$ & $\begin{array}{l}\text { 1. Developed a } \\
\text { relationship-oriented } \\
\text { framework for sexual risk } \\
\text { behavior for African } \\
\text { American, } \\
\text { methamphetamine- } \\
\text { involved male couples } \\
\text { 2. Adapted Couples an } \\
\text { intervention for } \\
\text { heterosexual couples for } \\
\text { African American } \\
\text { couples by adapting and } \\
\text { revising activities }\end{array}$ \\
\hline $\begin{array}{l}\text { Williams } \\
\text { (2009) }\end{array}$ & $\begin{array}{l}58 \text { African } \\
\text { American } \\
\text { MSMW }\end{array}$ & $\begin{array}{l}\text { Los } \\
\text { Angeles }\end{array}$ & $\begin{array}{l}\text { Men of African Legacy } \\
\text { Empowering Self } \\
\text { (MAALES) }\end{array}$ & $\begin{array}{l}\text { Theory of Reasoned } \\
\text { Action and Planned } \\
\text { Behavior, } \\
\text { Empowerment } \\
\text { Theory, Critical } \\
\text { Thinking and } \\
\text { Cultural Affirmation } \\
\text { Model }\end{array}$ & $\begin{array}{l}\text { Formative research } \\
\text { for intervention } \\
\text { adaptation }\end{array}$ & $\begin{array}{l}9 \text { focus group } \\
\text { discussions, } 20 \\
\text { individual } \\
\text { interviews, and } \\
\text { a pilot } \\
\text { intervention } \\
\text { session }\end{array}$ & $\begin{array}{l}\text { 1. Developed a culturally } \\
\text { congruent intervention } \\
\text { for African American } \\
\text { MSMW } \\
\text { 2. Early evaluation and } \\
\text { case studies indicate } \\
\text { high level of participant } \\
\text { satisfaction and favorable } \\
\text { outcomes }\end{array}$ \\
\hline
\end{tabular}

condition will be compared to control condition that is a one two-hour internet session that aims to improve general health. A Randomized Control Trail of the Bruthas Project is assessing the effect of an individual-level HIV prevention intervention for MSMW. The intervention is delivered in four sessions by trained counselors and covers topics such as HIV transmission, sexual communication skills, and condom use. RISE is an individual-level intervention for black MSMW that uses a randomized comparison group design. RISE involves 6 two-hour coaching interventions with a trained counselor that covers topics such as coping, stress reduction, and sexual health. In addition, MyLife MyStyle Evaluation Project is comparing the effectiveness of the MyLife MyStyle intervention to decrease the occurrence of unprotected anal sex among participants compared to a wait-list control group. Black Men Evolving Behavioral HIV Prevention Intervention for Black MSM (B-ME) is a two and a half day HIV prevention and risk reduction retreat. The study uses a randomized control group design to compare the effects of the intervention arm to a standard of care control arm.

\section{Discussion}

We identified 12 interventions in the peer review literature for black MSM that had been rigorously tested. Seven of these interventions used a randomized comparison group design, the gold standard in study design. We identified $8 \mathrm{HIV}$ prevention interventions for black MSM that reduced unprotected anal intercourse among study participants and 5 of these reached statistical significance. The success of these interventions suggests that behavior change interventions are effective at reducing HIV risk behaviors among black MSM. We were also pleased to identify completed and on-going interventions that are tailored for sub-groups of MSM with unique needs such as MSMW, drug-users, and youth. 
Interventions that have been shown to effectively reduce HIV risk behaviors should be used to inform evidencebased programs that are implemented on a wider scale and in a diversity of settings.

We also identified four formative research studies. These studies provide valuable information on the process of intervention development and on feasibility testing which can help to inform researchers and practioners as they develop and adapt interventions.

Behavior-change interventions that address areas such as healthy relationships, relationship dynamics, the social context of HIV risk, and risk reduction are valuable for HIV prevention, especially for HIV- positive black MSM. However, the high rates of HIV among black MSM cannot be explained by differences in HIV risk behavior [2]. Therefore, relying solely on behavioral interventions that have an endpoint of reducing risk behavior will most likely not have a population-level effect on HIV infection among black MSM. Research indicates that elevated HIV rates among black MSM can be explained by high rates of undiagnosed seropositivity, high rates of STIs, low use of ART and low ART adherence [2,23,24]. Despite this, we identified a small number of studies of interventions to increase use of HIV testing or treatment services among black MSM. We identified one intervention aimed to increase HIV testing among black MSM as well as SPNS, a national program that included eight linkage-to-care programs for young HIV-positive MSM of color.

To increase the number of seropositive black MSM who are aware of their HIV status and in HIV care and treatment, there is a great need for comprehensive HIV testing, linkage to care, and retention in care intervention studies for black MSM. Studies are needed that operate across various levels, including the health systems level and the individual level. At the health systems level, intervention studies are needed to test the effectiveness of developing well-defined systems that operate across and within organizations working with People Living with HIV (PLWH) to identify, link, and retain black MSM living with HIV into culturally appropriate HIV care and treatment. The SPNS's enhanced linkage to care program found that feeling respected at the clinic was important for retention in care [14]. Future intervention studies for black MSM should address the health care environment characteristics that promote linkage and retention in care among black MSM. At the individual level, studies are needed to test the effectiveness of interventions that offer outreach, linkage to care, retention, and ART adherence support services to black MSM. Programs such as ARTAS-I and ARTAS-II have shown that brief case management can successfully increase rates of linkage to care $[25,26]$, HIV systems navigation, an adaptation of patient navigation, has been found to successfully reduce barriers to care and improve health outcomes [27], and several adherence interventions, including social support interventions and case management interventions, have been proven effective [28]. These programs could be used to inform the development of intervention studies designed specifically for black MSM.

This review faces many limitations. First, we focused on studies in the peer-review literature and thus excluded research not accepted for publication as well as research in the gray literature. Thus, by focusing our search on studies with published findings we may have biased our results towards studies with significant findings and may have excluded studies with null findings. Second, this review also excludes interventions that have been developed and implemented but not rigorously studied. Evaluation research places an emphasis on internal and external validity [29] and, as a result, it requires methods and resources beyond the scope of many programs. Third, interventions that were not specifically designed for black MSM but which reach black MSM were also excluded. This includes HIV interventions for MSM regardless of race/ethnicity and HIV interventions for black men regardless of sexual orientation as well as broad initiatives around HIV testing, HIV prevention, HIV treatment, and provision of support services such as housing, substance abuse treatment, and job training. Fifth, we searched three databases using specific search terms to identify articles for potential inclusion in this study as well as NIH and CDC websites. While we feel our review was exhaustive, it is possible that we would identify additional articles if we expanded our list of search terms and the databases searched. Sixth, we included evaluations in our review that had a pre/post design and evaluations without a comparison group. These designs are limited in their ability to attribute findings to the intervention being assessed and have weak internal validity. Therefore these results should be interpreted with caution. Seventh, this review is qualitative and does not include a meta-analysis. Finally, we draw conclusions across studies without accounting for moderating factors.

\section{Conclusion}

This article provided a comprehensive review of implementation science among black MSM. We identified a total of 8 sexual risk reduction intervention studies among black MSM. Of these, 5 were found to significantly reduced HIV risk behaviors. Successful HIV behavior risk reduction interventions for black MSM should be used to inform evidence-based programming implemented on a wider scale. We identified no 
evaluated HIV identification, linkage to care, or retention in care programs for adult black MSM and a limited number for young black MSM. There is an imperative to develop, test, and scale up culturally appropriate HIV testing, linkage, retention, and adherence initiatives for black MSM. To successfully combat HIV/AIDS among black MSM interventions are needed that integrate behavioral, structural, and biomedical components.

\section{Competing interests}

The authors declare that they have no competing interests.

\section{Authors' contributions}

CM researched, analyzed, interpreted the data, and wrote the manuscript. $\mathrm{DH}$ contributed to the design, research, analysis, and interpretation of the findings. GM, KL, RK, KJ, DM critically revised the manuscript for important intellectual content. All authors read and approved the final manuscript.

\section{Acknowledgements}

We would like to acknowledge Dr. David Malebranche for contributing important intellectual content and critical review for this manuscript. This study was supported by contracts to The Johns Hopkins University from the National Minority AIDS Council (NMAC) (http://www.nmac.org/). NMAC had no role in study design, data collection or analysis. NMAC reviewed the interpretation of the data and provided suggested edits to a draft of the manuscript. Edits were accepted at the sole discretion of JHU.

\section{Disclaimer}

The findings and conclusions in this study are those of the authors and do not necessarily represent the views of the Centers for Disease Control and Prevention.

\section{Author details}

'Department of Health, Behavior and Society, Johns Hopkins Bloomberg School of Public Health, 624 N. Broadway, Baltimore, MD 21205, USA. ${ }^{2}$ Division of HIV/AIDS Prevention, Centers for Disease Control and Prevention, 1600 Clifton Rd, Atlanta, GA 30333, USA. ${ }^{3}$ National Minority AIDS Council, 1931 13th Street Northwest, Washington, DC 20009, USA.

Received: 14 May 2012 Accepted: 13 May 2013

Published: 2 July 2013

\section{References}

1. Centers for Disease Control and Prevention, In Book CDC Fact Sheet: New HIV Infections in the United States: CDC Fact Sheet: New HIV Infections in the United States. City: Editor ed.^eds; 2012.

2. Millett GA, Flores SA, Peterson JL, Bakeman R: Explaining disparities in HIV infection among black and white men who have sex with men: a metaanalysis of HIV risk behaviors. AIDS 2007, 21:2083-2091.

3. Millett GA, Peterson JL, Flores SA, Hart TA, Jeffries WL, Wilson PA, Rourke SB, Heilig CM, Elford J, Fenton KA, Remis RS: Comparisons of disparities and risks of HIV infection in black and other men who have sex with men in Canada, UK, and USA: a meta-analysis. Lancet 2012, 380:341-348.

4. Millett GA, Peterson JL, Wolitski RJ, Stall R: Greater risk for HIV infection of black men who have sex with men: a critical literature review. Am J Public Health 2006, 96:1007-1019.

5. Peterson JL, Jones KT: HIV prevention for black men who have sex with men in the United States. Am J Public Health 2009, 99:976-980.

6. Coleman $C L$, Jemmott $L$, Jemmott JB, Strumpf N, Ratcliffe S: Development of an HIV risk reduction intervention for older seropositive African American men. AIDS Patient Care STDS 2009, 23:647-655.

7. Koblin BA, Bonner S, Powell B, Metralexis P, Egan JE, Patterson J, Xu G, Hoover DR, Goodman K, Chin J, et al: A randomized trial of a behavioral intervention for Black men who have sex with men: The DiSH Study. AIDS 2012, 26:483-488.

8. Peterson JL, Coates TJ, Catania J, Hauck WW, Acree M, Daigle D, Hillard B, Middleton L, Hearst N: Evaluation of an HIV risk reduction intervention among African-American homosexual and bisexual men. AIDS 1996, 10:319-325.
9. Williams JK, Wyatt GE, Rivkin I, Ramamurthi HC, Li X, Liu H: Risk reduction for HIV-positive African American and Latino men with histories of childhood sexual abuse. Arch Sex Behav 2008, 37:763-772.

10. Wilton L, Herbst JH, Coury-Doniger P, Painter TM, English G, Alvarez ME, Scahill M, Roberson MA, Lucas B, Johnson WD, Carey JW: Efficacy of an HIV/STI prevention intervention for black men who have sex with men: findings from the Many Men, Many Voices (3MV) project. AIDS Behav 2009, 13:532-544.

11. Operario D, Smith CD, Arnold E, Kegeles S: The Bruthas Project: evaluation of a community-based HIV prevention intervention for African American men who have sex with men and women. AIDS EduC Prev 2010, 22:37-48.

12. Wu E, El-Bassel N, McVinney LD, Hess L, Remien RH, Charania M, Mansergh G: Feasibility and promise of a couple-based HIV/STI preventive intervention for methamphetamine-using, black men who have sex with men. AIDS Behav 2011, 15:1745-1754.

13. Jones KT, Gray P, Whiteside YO, Wang T, Bost D, Dunbar E, Foust E, Johnson WD: Evaluation of an HIV prevention intervention adapted for Black men who have sex with men. Am J Public Health 2008, 98:1043-1050.

14. Magnus M, Jones K, Phillips G 2nd, Binson D, Hightow-Weidman LB, Richards-Clarke C, Wohl AR, Outlaw A, Giordano TP, Quamina A, et al: Characteristics associated with retention among African American and Latino adolescent HIV-positive men: results from the outreach, care, and prevention to engage HIV-seropositive young MSM of color special project of national significance initiative. J Acquir Immune Defic Syndr 2010, 53:529-536.

15. Outlaw AY, Naar-King S, Parsons JT, Green-Jones M, Janisse H, Secord E: Using motivational interviewing in HIV field outreach with young African American men who have sex with men: a randomized clinical trial. Am J Public Health 2010, 100(Suppl 1):S146-151.

16. Miller WR, Rollnick S: Motivational Interviewing: Preparing People for Change. New York: Guilford Press; 2002.

17. Wohl AR, Garland WH, Wu J, Au CW, Boger A, Dierst-Davies R, Carter J, Carpio F, Jordan W: A youth-focused case management intervention to engage and retain young gay men of color in HIV care. AIDS Care 2011, 23:988-997.

18. Hightow-Weidman LB, Smith JC, Valera E, Matthews DD, Lyons P: Keeping them in "STYLE": finding, linking, and retaining young HIV-positive black and Latino men who have sex with men in care. AIDS Patient Care STDS 2011, 25:37-45.

19. Hightow-Weidman LB, Fowler B, Kibe J, McCoy R, Pike E, Calabria M, Adimora A: HealthMpowerment.org: development of a theory-based HIV/ STI website for young black MSM. AIDS Educ Prev 2011, 23:1-12.

20. Williams JK, Ramamurthi HC, Manago C, Harawa NT: Learning from successful interventions: A culturally congruent HIV risk-reduction intervention for African American men who have sex with men and women. Am J Public Health 2009, 99:1008-1012.

21. Wu E, El-Bassel N, Donald McVinney L, Fontaine YM, Hess L: Adaptation of a Couple-Based HIV Intervention for Methamphetamine-Involved African American Men who have Sex with Men. Open AIDS J 2010, 4:123-131.

22. Jaganath D, Gill HK, Cohen AC, Young SD: Harnessing Online Peer Education (HOPE): integrating C-POL and social media to train peer leaders in HIV prevention. AIDS Care 2011.

23. Oster AM, Wiegand RE, Sionean C, Miles IJ, Thomas PE, Melendez-Morales L, Le BC, Millett GA: Understanding disparities in HIV infection between black and white MSM in the United States. AIDS 2011, 25:1103-1112.

24. CDC: Prevalence and awareness of HIV infection among men who have sex with men -- 21 cities, United States, 2008. MMWR Morb Mortal Wkly Rep 2010, 59:1201-1207.

25. Craw JA, Gardner LI, Marks G, Rapp RC, Bosshart J, Duffus WA Rossman A, Coughlin SL, Gruber D, Safford LA, et al: Brief strengthsbased case management promotes entry into HIV medical care: results of the antiretroviral treatment access study-II. J Acquir Immune Defic Syndr 2008, 47:597-606.

26. Gardner LI, Metsch LR, Anderson-Mahoney P, Loughlin AM, del Rio C, Strathdee S, Sansom SL, Siegal HA, Greenberg AE, Holmberg SD: Efficacy of a brief case management intervention to link recently diagnosed HIV-infected persons to care. AIDS 2005, 19:423-431.

27. Bradford JB, Coleman S, Cunningham W: HIV System Navigation: an emerging model to improve HIV care access. AIDS Patient Care STDS 2007, 21(Supp| 1):S49-58. 
28. Simoni JM, Amico KR, Pearson CR, Malow R: Strategies for promoting adherence to antiretroviral therapy: a review of the literature. Curr Infect Dis Rep 2008, 10:515-521.

29. Padian NS, Holmes CB, McCoy SI, Lyerla R, Bouey PD, Goosby EP: Implementation science for the US President's Emergency Plan for AIDS Relief (PEPFAR). J Acquir Immune Defic Syndr 2011, 56:199-203.

doi:10.1186/1471-2458-13-625

Cite this article as: Maulsby et al:: A systematic review of HIV interventions for black men who have sex with men (MSM). BMC Public Health 2013 13:625.

\section{Submit your next manuscript to BioMed Central} and take full advantage of:

- Convenient online submission

- Thorough peer review

- No space constraints or color figure charges

- Immediate publication on acceptance

- Inclusion in PubMed, CAS, Scopus and Google Scholar

- Research which is freely available for redistribution 